\title{
FLORAS OF THE MIDDLE EAST: A QUANTITATIVE ANALYSIS AND BIOGEOGRAPHY OF THE FLORA OF IRAQ
}

\author{
S. A. GhazAnfar ${ }^{1} \&$ T. McDaniel ${ }^{2}$
}

\begin{abstract}
The descriptive flora of Iraq is incomplete, with \pm 900 species yet to be described. However, names of all species with their distribution in the different physiographic districts of Iraq are databased (in BRAHMS) from information obtained from published sources and herbarium records. A quantitative analysis of the flora shows \pm 3300 species (accepted names) in 908 genera belonging to 136 families of flowering plants. The families Asteraceae (409 spp.), Fabaceae (393 spp.), Poaceae (264 spp.), Brassicaceae (195 spp.) and Apiaceae (155 spp.) are the largest. An analysis of the distribution of the flora in the different physiographic regions and districts of Iraq shows the Mountain Region (northern mountains of Iraq) and the Central Alluvial Plains District in the Lower Mesopotamian Region to be the most species rich. Iraq is influenced by two major phytochoria, the Saharo-Sindian and the Irano-Turanian, which are subdivided into regional phytochoria specific to the Middle East region. Endemism is high in the Irano-Turanian region of Iraq which occupies the Mountain and major part of the Upper Plains and Foothills Regions. These Regions also contain the majority of the endemic and near endemic species. Biodiversity surveys carried out by Nature Iraq during 2005-2010 propose 88 Key Biodiversity Areas in Iraq. The National Report on Biodiversity in Iraq (CBD) outlines the threats to biodiversity and habitats in Iraq and a National Biodiversity Strategy and Action Plan for the protection and conservation of species-rich and biodiverse habitats.
\end{abstract}

Keywords. Biogeography, floristics, Iraq, Middle East, vegetation.

\section{INTR ODUCTION}

The Middle East is one of the most important regions of the Old World, not only with respect to its development of many of the earliest human civilisations and domestication of food crops but also from a geobotanical and floristic viewpoint (Zohary, 1973; Zohary et al., 2012).

For the purpose of this paper, the Middle East is taken to include Egypt (and Sinai), Turkey (and the Aegean Islands), Lebanon, Syria, Israel, Palestine, Jordan, countries of the Arabian Peninsula (Bahrain, Kuwait, Oman, Qatar, Saudi Arabia, Yemen and the United Arab Emirates), Iraq and Iran, excluding Sudan and countries of central Asia, Cyprus, Crete and Socotra (Fig. 1).

${ }^{1}$ Royal Botanic Gardens, Kew, Richmond, Surrey TW9 3AB, UK. E-mail for correspondence: s.ghazanfar@kew.org

2 Sandwich student at Royal Botanic Gardens, Kew (2012) from University of Bath. 


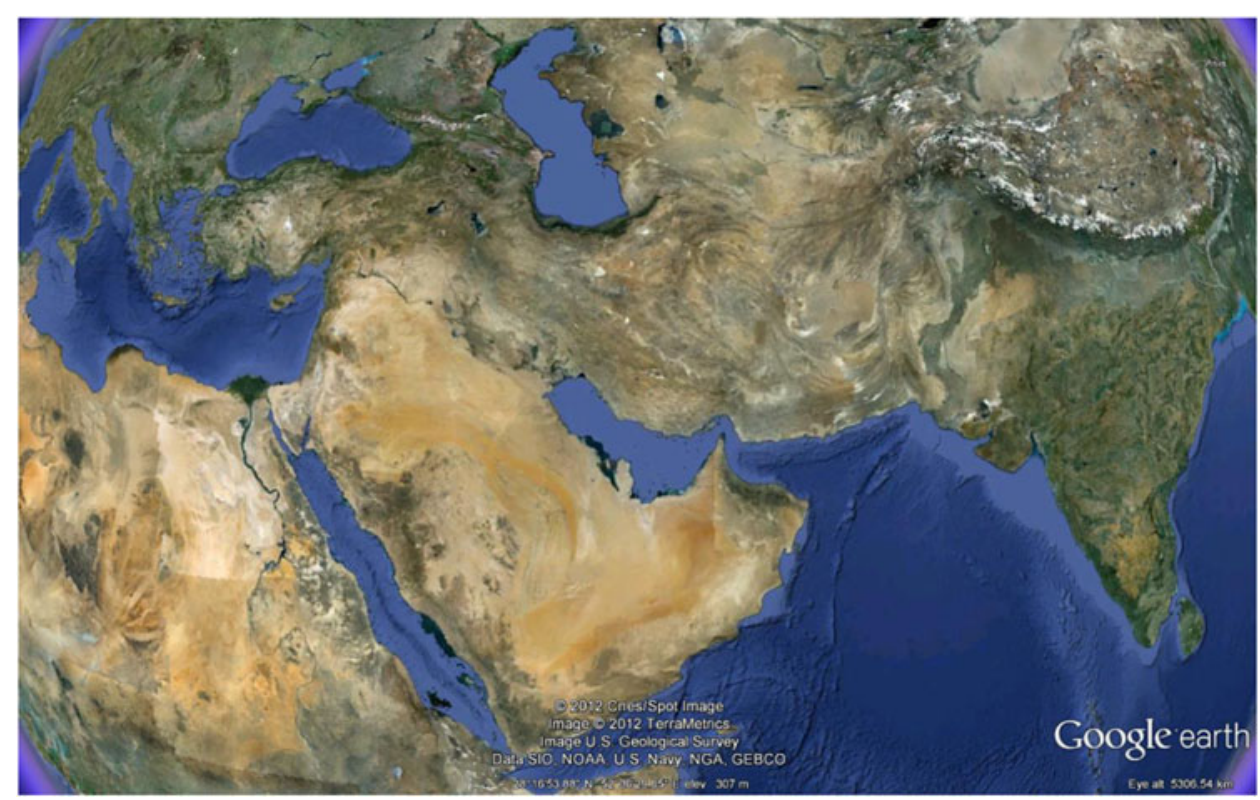

FIG. 1. The Middle East region.

The Middle East has a diverse physiography composed of large gravel and sandy deserts, upland plateaux and mountain ranges. The region lies at the edge of a large tectonic plate such that the Arabian Peninsula is pulling away from Africa, and parts of the Anatolian Peninsula (Turkey) are sliding past parts of Asia. Continental rifting has caused some areas to be below sea level, such as the Dead Sea located between Israel and Jordan.

The Arabian Peninsula lies between the Red Sea and Persian Gulf and is characterised by large areas of gravel and sand desert. The Arabian Desert, one of the largest deserts on Earth, stretches from Yemen to the Persian Gulf and from Oman to Jordan and Iraq. It occupies most of the Arabian Peninsula, with an estimated area of $2,330,000 \mathrm{~km}^{2}$. A large part of it, covering most of southern Saudi Arabia, is the hyper-arid Ar Rub' Al Khali, also known as the Empty Quarter. It is the largest (only sand) desert in the world and well known for its linear sand dunes that can extend for over 25 miles. Ad Dahna' is the northern expanse that connects to the An Nafud Desert which lies in western Saudi Arabia and is characterised by gigantic sand dunes, some reaching more than $30 \mathrm{~m}$ in height. Large areas of deserts are saline with inland sabkhas (salt flats); Umm as Samim, a big inland salt plain (a former lake) in western Oman, is one of the largest salt plains in Arabia (Glennie, 2005).

The Syrian Desert, also part of the Arabian Desert $\left(518,000 \mathrm{~km}^{2}\right)$, covers parts of Jordan, Syria, Saudi Arabia and western Iraq. Very little rain falls in this region but nomads inhabit the desert, raising cattle and camels. Oil pipelines are commonplace, as well as some scattered oases. 
Dash-e-Lut and Dash-e-Kavir are desert regions in Iran. Dash-e-Lut, in eastern Iran, is a wind-blown desert bowl completely surrounded by mountains and may be one of the hottest and driest spots of the world in the summer months; Dash-e-Kavir, a plateau in north-central Iran, often referred to as the 'Great Salt Desert', is the largest desert in the country and is mostly uninhabited land, covered with crusty salt ridges, surrounded by undulating gravelly Artemisia desert.

The Anatolian Plateau is a generally barren and arid plateau of central Turkey about $500 \mathrm{~m}$ in elevation. Farming and livestock are common and scattered towns and villages cover the landscape (Güner et al., 2012).

Mountains are of great floristic and ecological importance in the Middle East. They are centres of species richness and radiation and are of biogeographical importance. They also provide refugia where several relict and disjunct species are found. The Asir and Hejaz Mountains run along the Saudi Arabian border with the Red Sea, averaging 1829-2130 $\mathrm{m}$ in elevation. A low range of mountains, the Hardamawt range of Yemen, averages about $1067 \mathrm{~m}$, with the highest peak at $2440 \mathrm{~m}$ (Glennie, 1995, 2005). The rugged chain of the Taurus Mountains extends across southern Turkey to its borders with Iraq and Iran. The highest point (Mt Ararat) is located in the Eastern Taurus range. This extinct volcano is $5137 \mathrm{~m}$ high and is considered by biblical historians to be the place where Noah's Ark landed. The Elburz Mountains extend for almost $1000 \mathrm{~km}$ along Iran's northern border with the Caspian Sea and average over $2750 \mathrm{~m}$, with the highest point at Mt Damavand, a dormant volcano at $5670 \mathrm{~m}$. Important to biodiversity for Iran, Iraq and Turkey is the Zagros mountain range which begins in northwestern Iran and runs the whole length of the western and southwestern Iranian plateau and ends at the Strait of Hormouz. Remnants of oak (Quercus brantii) woodland, which once dominated these mountains, can still be found. These mountains and steppes are also home to several ancestors of food plants such as pistachio, almond, wheat, barley, lentil, walnut, plum, apricot, pomegranate and grape which can be found growing wild in the mountains (Frey et al., 1986).

Despite the high mountains, large parts of the Middle East, especially the Arabian Peninsula, are arid and lack water resources. Two rivers, the Tigris and the Euphrates, flow through parts of this region. The Euphrates rises in the Caucasus Mountains of Armenia, flows southwesterly across east-central Turkey, then generally southeast through Syria and Iraq and into the Persian Gulf. It joins with the Tigris in southern Iraq and from that junction continues as Shatt al Arab. The Euphrates is the longest river in the Middle East and historically important in ancient history. The Tigris rises in the mountains of southern Turkey and flows southeast through Iraq, merging with the Euphrates in the south and flowing into the Persian Gulf. The river has numerous small tributaries running from its eastern bank. The Jordan River flows from Mt Hermon in Lebanon through Jordan into the Dead Sea, and several large rivers in Iran are critical for agriculture in the region.

Climatically the Middle East is arid, with hot, dry summers and mild winters. Rainfall and temperature vary considerably across the region and even within countries. The Caspian Sea coast of northern Iran receives up to $2000 \mathrm{~mm}$ of rain a year, 
while the desert regions of Iran and the Arabian Peninsula often receive no rain at all for many years (Djamali et al., 2011). Temperatures also vary by region. Across the Middle East, summer temperatures are usually around $28-29^{\circ} \mathrm{C}$ but often rise above $37^{\circ} \mathrm{C}$. In Baghdad, the record high is $49^{\circ} \mathrm{C}$; in Basra, $50^{\circ} \mathrm{C}$, the highest temperature recorded in any major Middle Eastern city. In the Saudi Arabian desert, however, temperatures over $48^{\circ} \mathrm{C}$ are common. Most storms crossing the Middle East become dust- or sandstorms when strong winds blow and stir the dry desert surface (Al-Dabbas et al., 2012).

Low-lying coastal regions of the Arabian Peninsula, Jordan and Iraq and those bordering the Mediterranean Sea have much more moderate winter temperatures: Jeddah in western Saudi Arabia averages $23^{\circ} \mathrm{C}$ in January and $31.5^{\circ} \mathrm{C}$ in July. Lowland desert areas in the interior regions of the Arabian Peninsula, Iran, Iraq and Egypt have extreme heat in the winter with temperatures sometimes reaching $25^{\circ} \mathrm{C}$ or higher.

\section{FLORISTICS AND BIOGEOGRAPHY}

We do not know the exact number of plant species in the Middle East, but an estimate of 13,500 is plausible. Country-wise Turkey and Iran are the richest in species, with almost two to three times the number of plant species found in other countries. Recent descriptive floras for several of the countries of the Middle East are complete, whilst others are at various stages of completion (Table 1). Historical floras such as Boissier's Flora Orientalis (1867-1888), Post's Flora of Syria, Palestine and Sinai (1932-1933), Rechinger's Flora Iranica (1963-2012), Davis's Flora of Turkey (1965-1985) and Zohary's Flora Palaestina (1966-1986), cover most of the Middle East. These floras have variously been the basis of regional or country floras.

At a global scale, the Middle East lies in the transition zone between two major biogeographic units, the Palaearctic and Afrotropical ecozones, resulting in a unique biological diversity of outstanding biogeographical significance (Olson et al., 2001) (Fig. 2). The Mediterranean Basin (of the Palaearctic ecozone - land bordering the Mediterranean Sea) consists of Mediterranean forests, woodlands and scrub and has about 13,000 endemic species. It is also one of the world's most endangered biogeographic regions with an estimated $4 \%$ of the region's original vegetation remaining, and has been designated one of the world's biodiversity hotspots (Olson et al., 2001; Mildrexler et al., 2005). The Iranian plateau is home to dry, steppe grasslands and desert basins, with montane forests, woodlands and grasslands in the region's high mountains. In the Middle East, the Arabian Desert separates the Palaearctic and Afrotropic ecozones and forms a transition zone between the Afrotropic and Mediterranean Basin to the north. The southern Arabian woodlands found mostly in southwestern parts of the Arabian Peninsula (mostly Yemen, parts of western Oman and southwestern Saudi Arabia) include a few permanent and seasonal forests with elements of the East African and Ethiopian floras. Other woodlands are scattered across the land; these are very small and are predominantly juniper or acacia woodlands (Zohary, 1973; Ghazanfar \& Fisher, 1998). 
TA B LE 1. Approximate number of taxa in the countries of the Middle East and the status of their Floras

\begin{tabular}{lll}
\hline \hline Country & No. of taxa & Floras \\
\hline Turkey & 9753 & Davis (ed.) Fl. Turk. Vols 1-9 (1965-1985) - complete; Güner et al. (2012 - checklist) \\
Iran & 7300 & Rechinger (ed.) Fl. Iranica (1963-2012) - incomplete (see Akhani, 2006) \\
Syria & 3500 & Post, Fl. Syria, Palestine \& Sinai Vols 1 \& 2 (1932, 1933) - complete but outdated \\
Iraq & 3220 & Townsend \& Guest (eds) Fl. Iraq (1966-1985); Ghazanfar \& Edmondson (2013-) - incomplete \\
Yemen & 2838 & Wood, Fl. Yemen (1997) - complete but not for S Yemen; Al-Khulaidi (2013 - checklist) \\
Palestine (incl. Israel & 2700 & Zohary, Fl. Palaestina Vols 1-4 (1966, 1972, 1986) - complete - being updated \\
$\quad$ and eastern Jordan) & & \\
Lebanon (incl. Syria) & 2606 & Mouterde (1970) - complete but outdated \\
Jordan & 2521 & No Flora - incomplete \\
Saudi Arabia & 2281 & Chaudhary, Fl. Saudi Arabia Vols 1-3 (1999, 2001) - complete; Mandaville (1990) \\
Egypt & 2145 & Boulos, Fl. Egypt Vols 1-4 (1999, 2000, 2002, 2005) \& checklist (2009) - complete \\
Oman & 1211 & Ghazanfar, Fl. Oman Vols 1-3 (2003, 2007, 2015) - incomplete \\
United Arab Emirates & 650 & Western (1989); Jongbloed (2003); Karim \& Fawzi, Fl. United Arab Emirates (2007) - complete \\
Kuwait & 407 & Daoud \& Al-Rawi, Fl. Kuwait Vol. 1 (1985); Al-Rawi, Vol. 2 (1987) - complete but outdated \\
Qatar & 270 & Batanouny, Fl. Qatar (1981); Norton et al. (2009- checklist); Abdel-Bari (2012) - complete \\
Bahrain & 250 & Phillips (1988); Cornes \& Cornes, Wild Flow. Pl. Bahrain (1989) - complete but outdated \\
\hline \hline
\end{tabular}



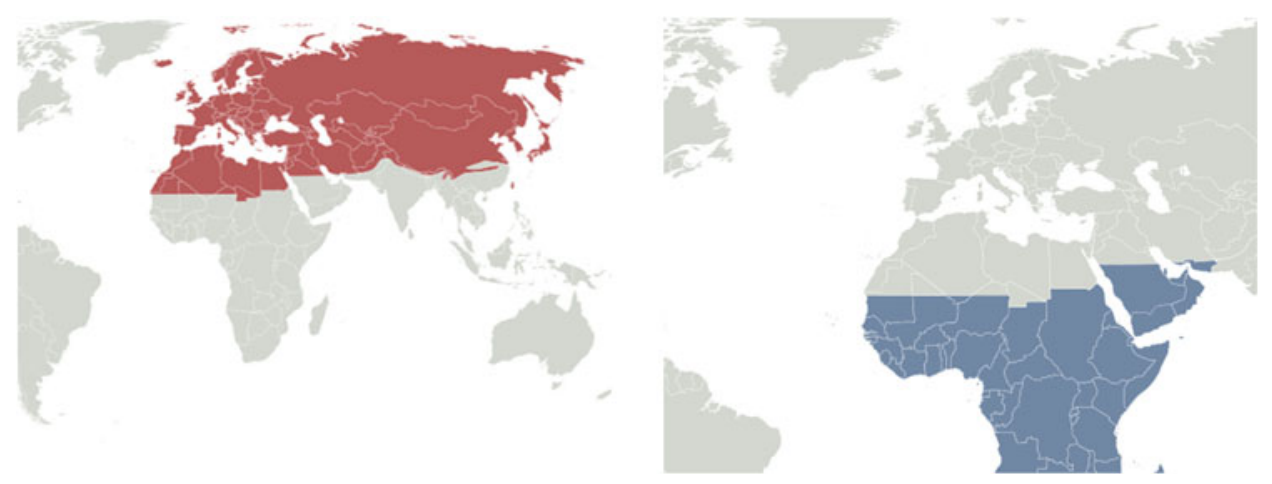

FIG. 2. Palaearctic (left) and Afrotropic (right) ecozones. From Olson et al. (2001).

Several genera have their main centres of distribution and representative endemic species in the Middle East. Notable amongst these are Acantholimon, Acanthophyllum, Astragalus, Centaurea, Cousinia, Dionysia, Nepeta, Phlomis, Salvia, Saponaria, Silene, Stachys, Thymus and Verbascum, and it is a very important centre of generic diversity of the Apiaceae and Brassicaceae (Zohary, 1973).

Briefly, the phytogeographical subdivisions of the Middle East as described by Zohary (1973) and revised by Léonard (1989) include:

1 The Euro-Siberian region, which includes Europe, western and northern Asia; the subregion Pontic (of the Euro-Siberian region) represented in the Middle East by the Euxinian and Hyrcanian subprovinces. These occupy the mountains of northern Turkey, southern slopes of the Elbruz Mountains and southern slopes of the Caspian Sea.

2 The Mediterranean region, which occupies a narrow belt along the Mediterranean Sea, with a gap between Palestine and Libya where the desert closely approaches the Mediterranean.

3 The Irano-Turanian region, which occupies about half of the Middle East, mainly $\mathrm{C}$ and E Turkey, Iran, Iraq, Syria and Palestine; it is floristically rich, high in endemism and a centre of radiation of several genera.

4 The Saharo-Sindian region, which occupies most of the Arabian Peninsula, southern Palestine and SE Iraq.

5 The Sudanian region, which occupies SW Arabia, Gulfs of Suez and Aqaba, Gulf of Oman and the Arabian Sea.

\section{FLORA OF IRAQ}

Iraq has a rich and diverse flora, with some \pm 3300 species found in its deserts, plains and mountains (Fig. 3). The descriptive Flora of Iraq started in 1965 as a joint project between the Royal Botanic Gardens, Kew and the Ministry of Agriculture, Baghdad. 


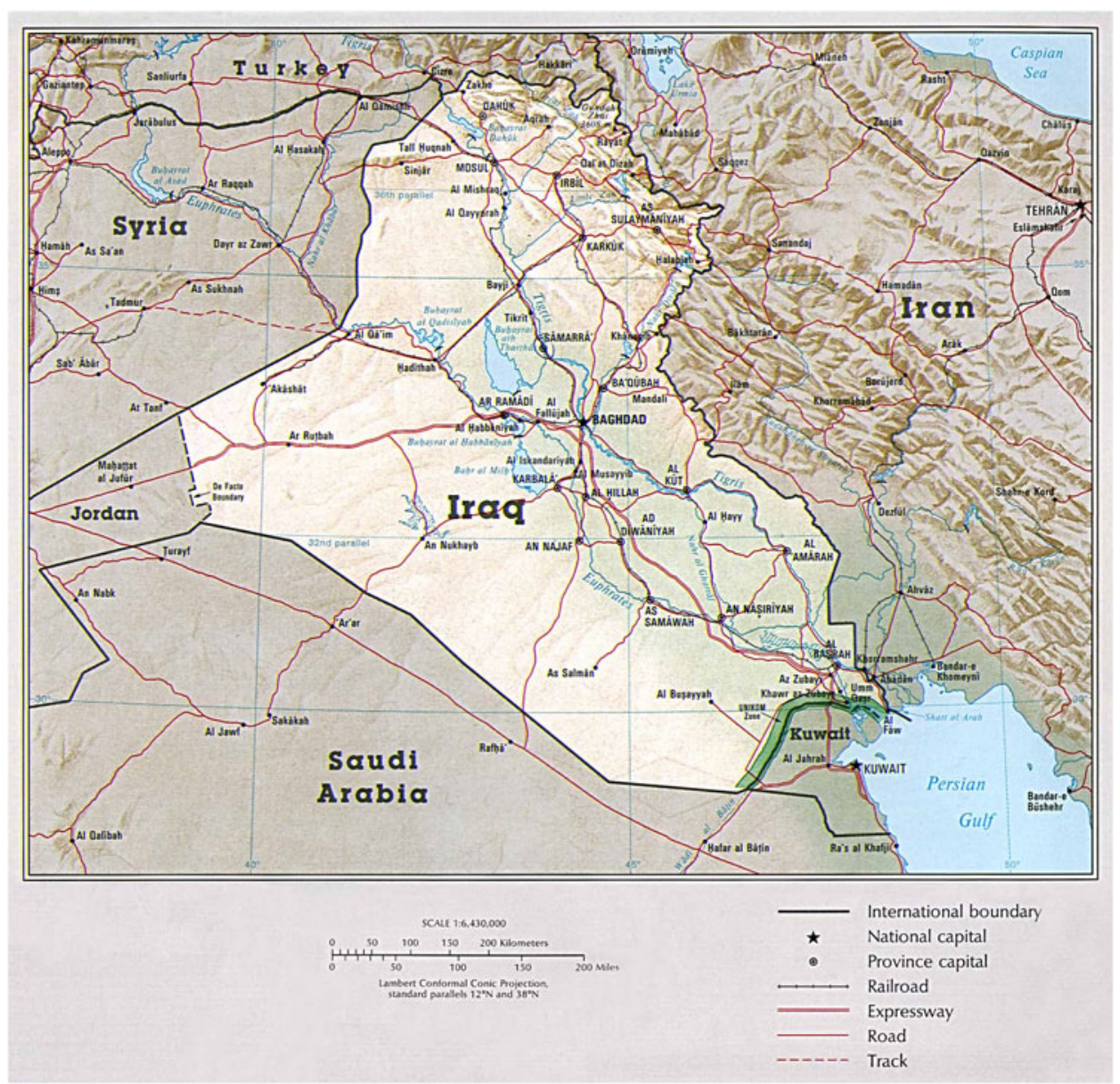

FIG. 3. Physical map of Iraq.

Nine volumes were planned and six were published between 1966 and 1985 (vols 1, 2, 3, 4 parts 1 \& 2, 8 and 9; covering some 1783 species) edited by A. Al-Rawi (Iraq), C. C. Townsend (Kew) and Evan Guest (Iraq) with the collaboration of the Botany Directorate of the Ministry of Agriculture and Agrarian Reform, Baghdad. Progress on the Flora was interrupted by political change in Iraq. Now, work has recommenced under the editorship of Shahina Ghazanfar and John Edmondson, with vol. 5(2) published in 2013 and vol. 5(1) now in press. The two remaining volumes (vols 6 and 7 to cover \pm 900 species) are at different stages of completion.

\subsection{Floristics}

The number of species in Iraq is estimated to be \pm 3300 . This number is tentative and will be confirmed once the flora is fully described and updated. The number of genera 
is 908 in 136 families (monocots 512; eudicots 2708). Asteraceae is the largest family with $>400$ species ( 50 monotypic genera), followed by Fabaceae (393 spp.), Poaceae (264 spp., 35 monotypic genera), Brassicaceae (195 spp., 30 monotypic genera) and Apiaceae (155 spp.) (Table 2; Fig. 4). Annuals make up more than a third of the flora in Iraq. Endemism is low with 181 endemic species recorded (5.6\%), most of them in the northern mountains. A further 97 near endemic species are found in the mountains of northern Iraq, SE Turkey and W Iran (see Fig. 5 for map of physiographic districts). Many of these species have been collected once or only a few times in Iraq (Table 3; Fig. 6).

An analysis of the distribution of species by physiographic regions and districts shows that the northern regions are the most species rich, with the Mountain Region containing $40 \%$ of the total flora (Figs 7, 8). It is not surprising that species richness is highest in the northern mountains as here the climate is most equable for plant growth, the physiography is diverse and there is an overlap of Turkish and Iranian floras. This region also constitutes the richest arboreal flora of the Kurdo-Zagrosian system (Zohary, 1973). The Central Alluvial Plains (LCA in Fig. 5) in the Lower Mesopotamian Region are also rich in species, and is where the majority of the halophytes, annuals and cosmopolitan species are found (Fig. 12).

T A B L E 2. The 20 largest plant families in Iraq

\begin{tabular}{lcc}
\hline \hline Family & No. of genera & No. of species \\
\hline Asteraceae & 118 & 409 \\
Fabaceae & 58 & 393 \\
Poaceae & 101 & 264 \\
Brassicaceae & 79 & 195 \\
Apiaceae & 67 & 155 \\
Boraginaceae & 30 & 140 \\
Scrophulariaceae s.1. & 20 & 138 \\
Caryophyllaceae & 29 & 125 \\
Liliaceae & 22 & 124 \\
Amaranthaceae: Chenopodioideae & 25 & 68 \\
Rosaceae & 20 & 64 \\
Cyperaceae & 15 & 63 \\
Rubiaceae & 12 & 63 \\
Euphorbiaceae & 7 & 51 \\
Solanaceae & 11 & 47 \\
Ranunculaceae & 7 & 45 \\
Convolvulaceae & 6 & 39 \\
Polygonaceae & 8 & 41 \\
Orchidaceae & 9 & 31 \\
Malvaceae & 8 & 29 \\
Papaveraceae & 5 & 29 \\
\hline \hline
\end{tabular}




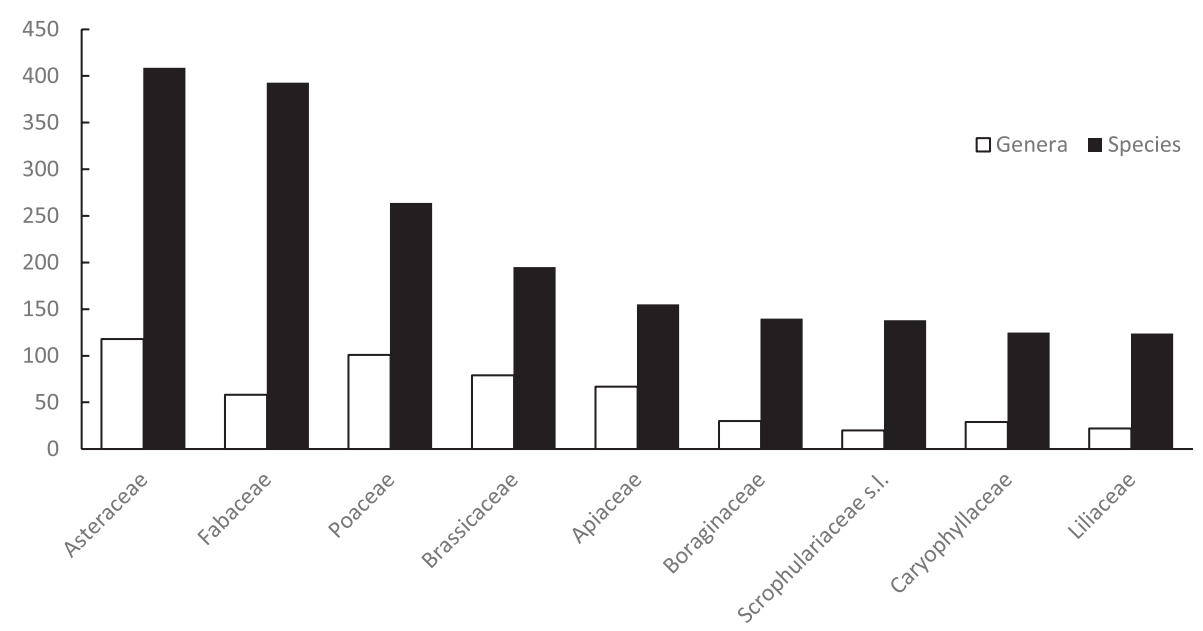

FIG. 4. Genera and species in families with $>100$ species in Iraq.

\subsection{Vegetation}

Volume 1 of the Flora of Iraq gives a detailed account of the vegetation and biogeography of Iraq (Guest \& Al-Rawi, 1966). A summary of the vegetation zones is given here.

Iraq can be divided into four major vegetation zones, each with its characteristic vegetation (Fig. 9):

\section{Desert Region}

Land classification: The Southern Desert and Sub-desert (steppe) bordering with Saudi Arabia, Jordan, Syria and Kuwait. Sand, gravel plains, rocky outcrops; river systems and marshes; sabkha and saline areas of alluvial plains of Lower Mesopotamia; cultivation.

Approx. area: $350,000-400,000 \mathrm{~km}^{2}$.

Altitude range: $50-950 \mathrm{~m}$. Annual rainfall: $<75-150 \mathrm{~mm}$.

Ecoregion: Arabian desert and east Sahero-Arabian xeric shrublands; Persian Gulf desert and semi-desert; Red Sea Nubo-Sindian tropical desert and semi-desert; South Iran Nubo-Sindian desert and semi-desert (Fig. 10).

Districts: DLJ, DGA, DWD, DSD, LEA, LCA, LSM, LBA (Fig. 5).

Vegetation: Sparse open scrub and halophytic communities: In sand with Haloxylon ammodendron (in sandy desert and on unstabilised sand dunes) and associates Panicum turgidum, Calligonum comosum and Cyperus conglomeratus. The Hammada salicornica community is the most characteristic and important community of the desert region of Iraq and is also widespread throughout the deserts of the Arabian Peninsula. 


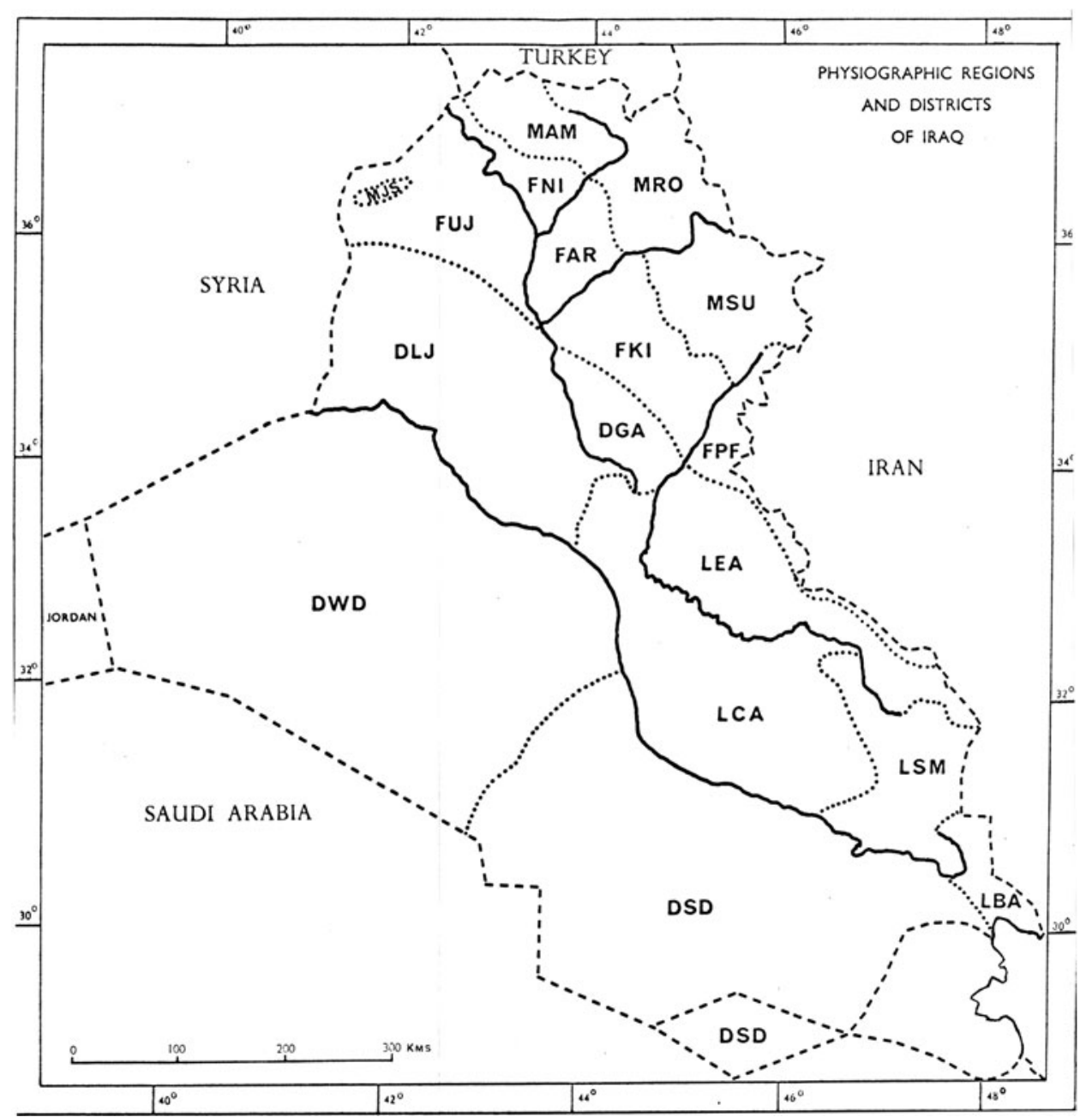

FIG. 5. Physiographic districts of Iraq. M - Mountains Region: MAM, Amadiya District; MRO, Rowanduz District; MSU, Sulaimaniya District; MJS, Jabal Sinjar District; F - Upper Plains and Foothills Region: FUJ, Upper Jazira District; FNI, Nineveh District; FAR, Arbil District; FKI, Kirkuk District; FPF, Persian Foothills District; D - Desert Plateau Region: DLJ, Lower Jazira District; DGA, Ghurfa-Adhaim District; DWD, Western Desert District; DSD, Southern Desert District; L - Lower Mesopotamian Region: LEA, Eastern Alluvial Plains District; LCA, Central Alluvial Plains District; LSM, Southern Marsh District; LBA, Basra Estuarine District. From Guest \& Al-Rawi (1966).

Associated species include Tetraena coccinea on sandy soil overlying saline flats, and Tamarix; other species include Anabasis articulata, Farsetia aegytiaca, Heliotropium ramosissimum s.1., Plantago ciliata, Rhanterium epapposum, Teucrium oliverianum, Ziziphus nummularia (in sandy depressions) and Seidlitzia rosmarinus (on higher ground at the edges of saline mud-flats). The most characteristic community of 
T A B LE 3. Number of endemic species in the plant families of the flora of Iraq

\begin{tabular}{llll}
\hline \hline Family & No. of species & Family & No. of species \\
\hline Asteraceae & 35 & Campanulaceae & 1 \\
Lamiaceae & 15 & Caryophyllaceae & 1 \\
Fabaceae & 14 & Cyperaceae & 1 \\
Brassicaceae & 10 & Dipsacaceae & 1 \\
Amaryllidaceae (incl. Alliaceae) & 7 & Geraniaceae & 1 \\
Apiaceae & 7 & Iridaceae & 1 \\
Rubiaceae & 7 & Orchidaceae & 1 \\
Scrophulariaceae & 6 & Papaveraceae & 1 \\
Asparagaceae & 4 & Plantaginaceae & 1 \\
Boraginaceae & 4 & Polygonaceae & 1 \\
Liliaceae & 4 & Ranunculaceae & 1 \\
Poaceae & 3 & Rosaceae & 1 \\
Linaceae & 2 & Urticaceae & 1 \\
Plumbaginaceae & 2 & Violaceae & 1 \\
& & Vitaceae & 1 \\
\hline \hline
\end{tabular}

sabkha areas prevalent on saline mud-flats in southwestern Iraq is dominated by Halocnemum strobilaceum; Aeluropus lagopoides and Cressa cretica are occasionally found in association with it. Bienertia cycloptera is found at the margins of small saline depressions in sandy areas. Sub-desert scrub: With Achillea fragrantissima, Artemisia herba-alba, Astragalus spp., Centaurea spp., Cousinia stenocephala, Phlomis bruguieri and Peganum harmala (on disturbed and waste ground); annuals Stipa capensis (dominant after rain), Plantago ovata, Astragalus tribuloides, A. annulatus, Medicago laciniatus, Gymnarrhena micrantha, Astericus pygmaeus, Neurada procumbens and Ifloga spicata.

Biogeography and endemism: Saharo-Sindian [Saharan region + Saharo-Arabian regional subzone]; endemism: 6 species.

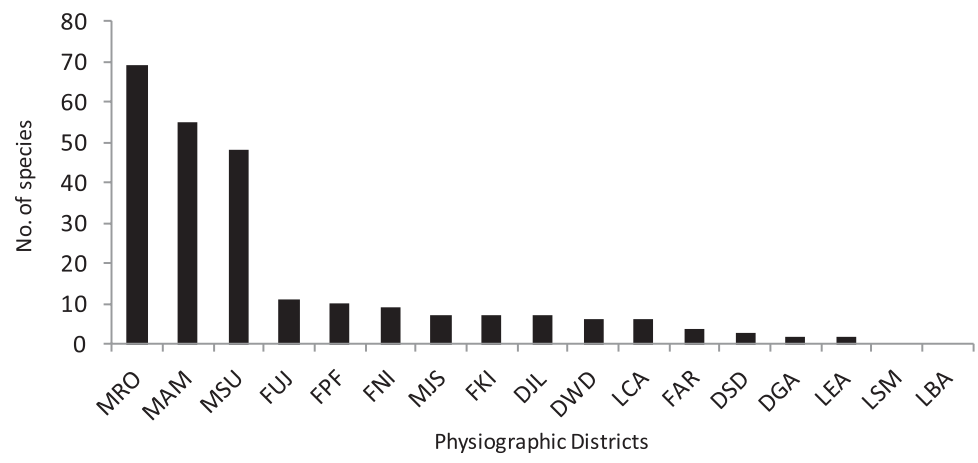

FIG. 6. Endemism in the physiogeographic districts of Iraq (see Fig. 5). 


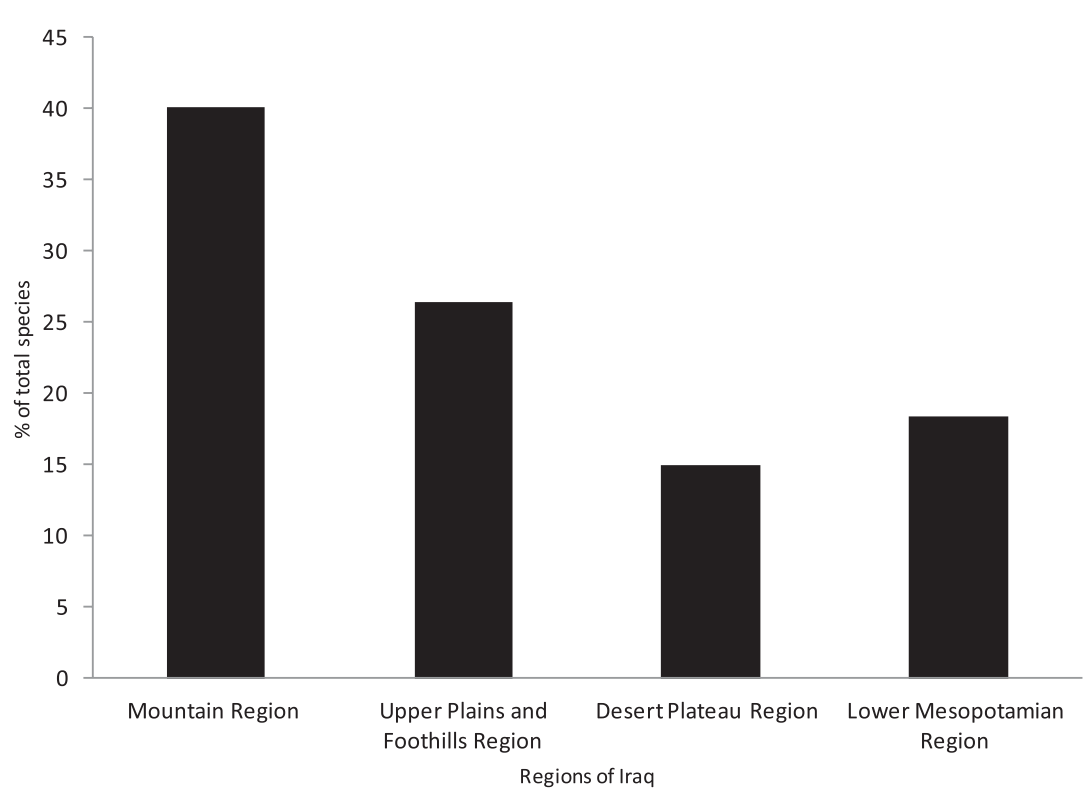

FIG. 7. Percentage of total species in different physiographic regions of Iraq.

\section{Steppe Region}

Land classification: This region includes the dry and moist steppes in northern Iraq, bordering Syria in the east and Iran in the west. In Iraq, it constitutes the upper plains to the foothills of the mountains; gravel plains, rocky outcrops; Great Zab R.; farming for winter crops.

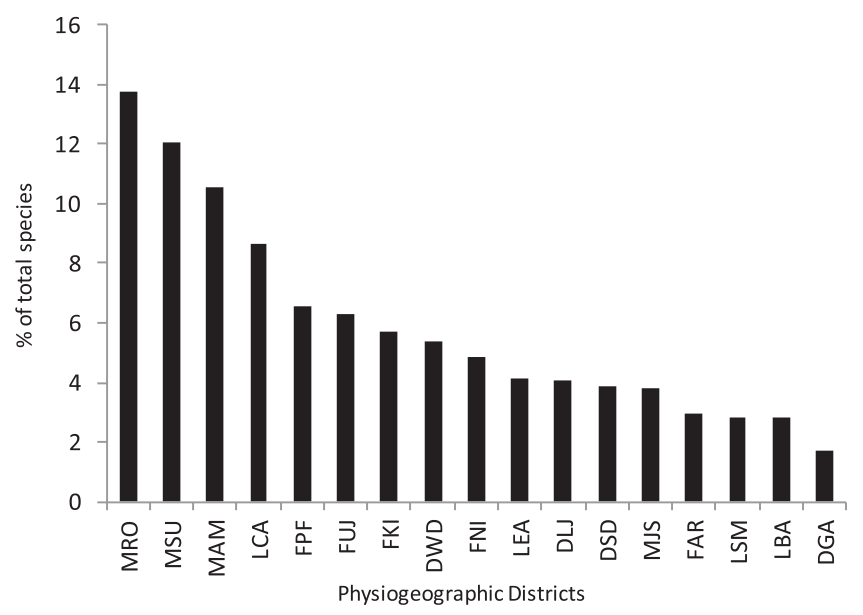

FIG. 8. Distribution of species per district in different physiographic regions of Iraq as outlined in the Flora of Iraq vol. 2 (see Fig. 5). 


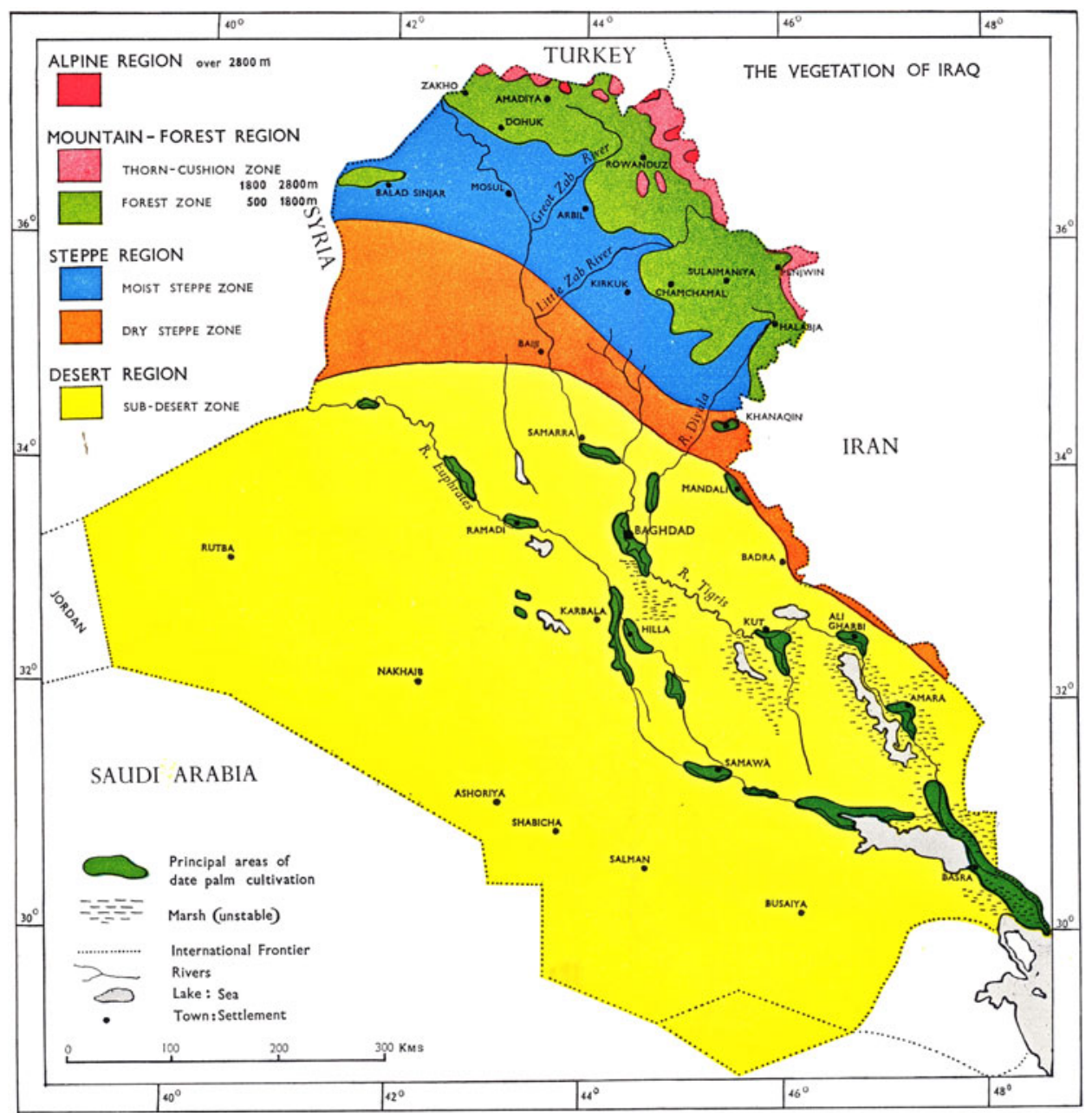

FIG. 9. Vegetation zones of Iraq. From Guest \& Al-Rawi (1966).

Approx. area: $65,000 \mathrm{~km}^{2}$.

Altitude range: Dry steppe 100-300 m \& moist steppe 300-500 m. Annual rainfall: 200-350 $\mathrm{mm} \& 350-500 \mathrm{~mm}$.

Ecoregion: Mesopotamian shrub desert; Middle East steppe (Fig. 10).

Districts: FUJ, FNI, FAR, FKI, FPF (Fig. 5).

Vegetation: Dry steppe: Sparse short grassland with scattered small shrubs. Characteristic vegetation of Poa bulbosa s.1., with Carex stenophylla and Ranunculus asiaticus. Remnants of Artemisia herba-alba and Achillea conferta. Other species include 


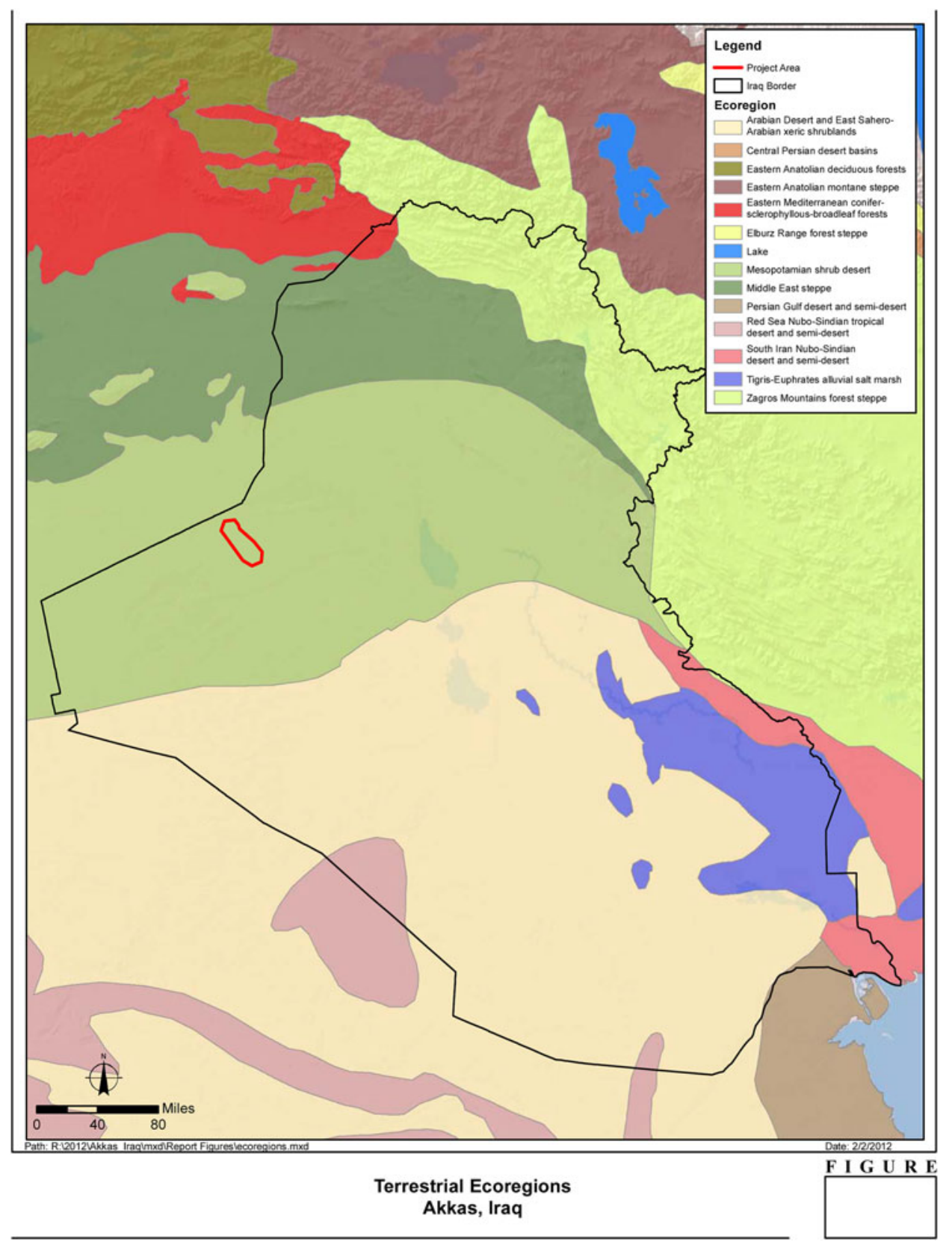

FIG. 10. Terrestrial ecoregions of Iraq. Adapted from Olson et al. (2001).

Astragalus mossulensis, A. dactylocarpus, Salvia palestina, S. compressa and Moltkia angustifolia; geophytes Ornithogalum ulophyllum, Gladiolus segetum, Bellevalia spp. and Muscari longipes. Dry steppe: Open grassland dominated by Pistacia and other 
small trees (original vegetation now destroyed through long-term cultivation and grazing). In uncultivated and protected areas, grassland with Poa bulbosa s.1., Hordeum bulbosum and Aegilops speltoides, herbs Anemone coronaria, Gundelia, Cousinia and Hypericum.

Biogeography and endemism: Mesopotamian Sub-region of Irano-Turanian; endemism: 9 species.

\section{Mountain-Forest Region}

Land classification: This region includes the northern mountains bordering Syria, Turkey and Iran. It also includes the upper altitudes of Jabal Sinjar. The region constitutes the Forest Zone and the Thorn-cushion Zone.

Approx. area: $30,000 \mathrm{~km}^{2}$.

Altitude range: Forest Zone 500-1800 m \& Thorn-cushion Zone 1750-3000 m. Annual rainfall: $700-1400 \mathrm{~mm} \&>1000 \mathrm{~mm}$, partly as snow.

Ecoregion: Zagros Mountains forest steppe (Fig. 10).

Districts: MAM, MRO, MSU, MJS (Fig. 5).

Vegetation: Forest Zone: Open to closed forest of Quercus spp. (Q. aegilops, Q. brantii, $Q$. infectoria, $Q$. libani) with Pistacia atlantica and $P$. khinjuk and pine forest with Pinus brutia var. eldarica. Where the forest vegetation is destroyed, the steppe vegetation tends to take over in the lower forest zone. Thorn-cushion Zone: Open shrubland with large shrubs of Astragalus, associated with Daphne acuminata, Lonicera arborea and low thorny shrubs of Acantholimon, Acanthophyllum and Cousinia.

Biogeography and endemism: Irano-Anatolian Sub-region of Irano-Turanian; endemism: 113 species.

\section{Alpine Region}

Land classification: This region includes the alpine zone of the northern mountains.

Approx. area: $100 \mathrm{~km}^{2}$.

Altitude range: $2750-3730 \mathrm{~m}$. Annual rainfall: $>1000 \mathrm{~mm}$, largely as snow.

Ecoregion: Zagros Mountains forest steppe (Fig. 10).

Districts: MAM, MRO, MSU (Fig. 5).

Vegetation: Perennial low herbs and shrubs of the families Asteraceae, Brassicaceae, Fabaceae, Lamiaceae, Plumbaginaceae and Poaceae form the dominant vegetation.

Biogeography and endemism: Irano-Anatolian Sub-region of Irano-Turanian. 


\subsection{Biogeography and endemism}

Biogeographical links based on the distribution of plant species in the physiogeographic districts and vegetation zones of Iraq suggest three phytochoria in Iraq (Fig. 11). We base our observations on the distribution of all taxa treated in the published volumes of the Flora of Iraq, Flora Iranica and unpublished sources (herbarium material) in each of the 17 physiogeographic districts of Iraq, as given in Flora of Iraq vol. 1 (Guest \& Al-Rawi, 1966) (Fig. 5). Using White's classification for Africa (White, 1983) and Léonard's extension of the phytochoria into SW Asia (Léonard, 1989; White \& Léonard, 1991), the three phytochoria are: (i) the Saharo-Sindian regional zone, subdivided into a Saharan regional subzone (SS1) and an Arabian regional subzone (SS2) [both belonging to the Saharo-Sindian regional zone (Léonard, 1981-1989); Sahara regional transitional zone (White, 1983); Nubo-Sindian Province of the Sudanese floristic region of the Palaearctic kingdom (Zohary, 1973)] and the Nubian-Sindian local centre of endemism (SS3); (ii) the Irano-Turanian regional centre of endemism; (iii) the Mediterranean-Saharan regional transitional zone. The number of endemic species in the plant families of the flora of Iraq is shown in Table 3.

\section{i. Saharo-Sindian regional zone}

Ecoregion: Arabian desert and east Saharo-Arabian xeric shrublands; Persian gulf desert and semi-desert.

The Saharo-Sindian regional zone is a large, ecologically diverse region that extends from the African Sahara to the desert of Baluchistan and Sind. In Iraq, it occupies most of the southern desert areas and is characterised generally by high temperatures and high diurnal fluctuation, low rainfall and high soil salinity. This zone is poor in species; vegetation is sparse, localised in depressions and absent altogether from some areas. Cultivation is present where subsurface water occurs and, in these oases, many cosmopolitan species and annuals are found. Two species, Hammada salicornica and Suaeda aegyptiaca, both found in Iraq, are endemic to this phytochorion.

The subzones of this large regional zone are indistinct but can be broadly recognised as below:

\section{a. Saharan regional subzone (SS1)}

The Saharan regional subzone (of the Saharo-Sindian regional zone) occupies the majority of the southern and western areas of Iraq. It extends from north Africa into southern Iraq, which is the northernmost limit of this subzone. In Iraq, the desert region vegetation as described in Section 2.2 constitutes this large and widespread floristic region.

The vegetation of the Saharan regional subzone fits in with the Acacia communities and the Halogypsophilous vegetation described by White (1983). Of the larger woody plants Acacia nilotica, Calotropis procera and Salvadora persica are present amongst herbs and shrubs including Cassia italica and Seetzenia africana and the grass Panicum turgidum. Of the halogypsophilous vegetation, species of Caroxylon (= Salsola s.l. p.p.), 


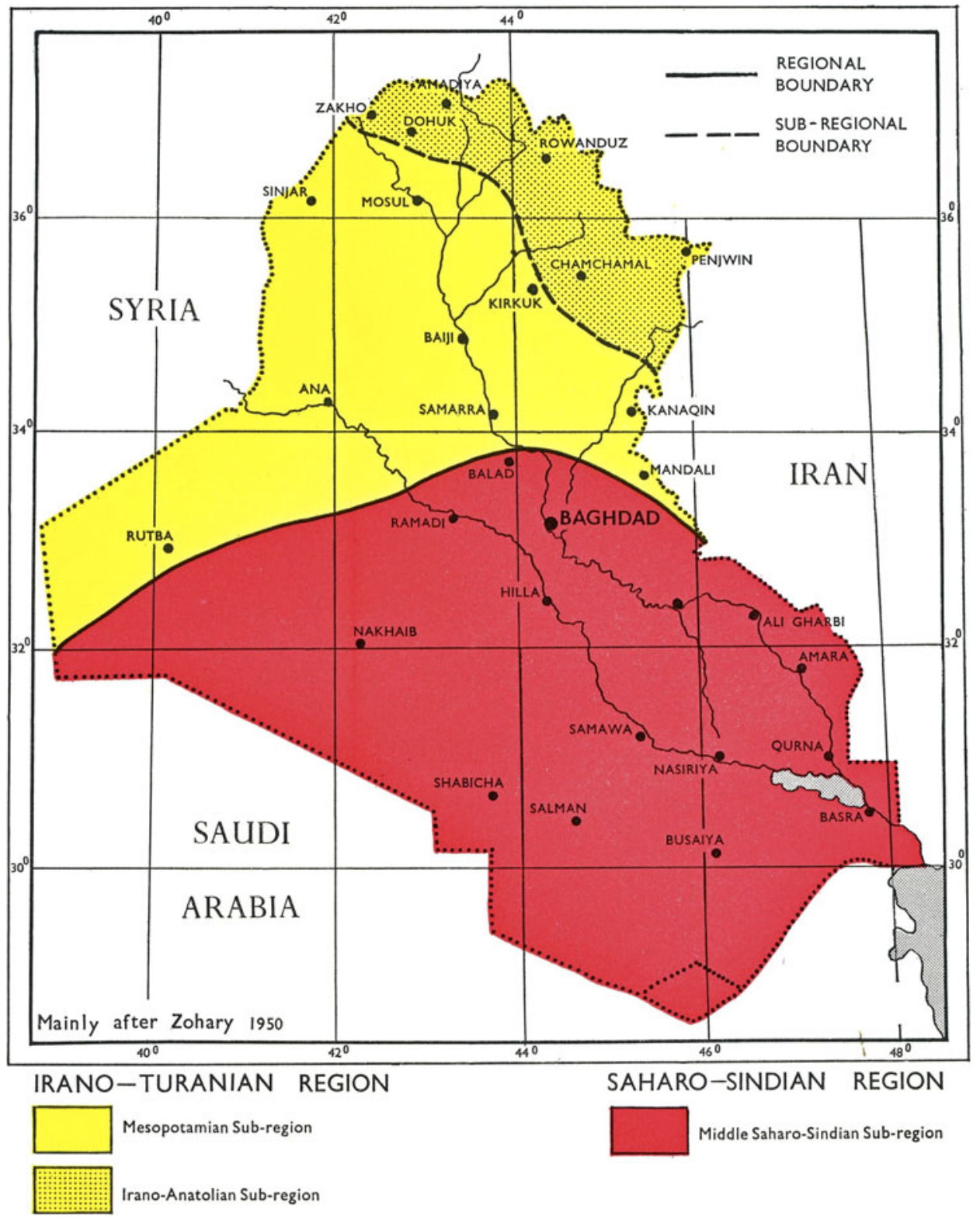

FIG. 11. Phytogeographic divisions of Iraq. From Guest \& Al-Rawi (1966).

Salsola, Suaeda and Tetraena are present. Representatives of Saharan endemic genera such as Anastatica, Neurada, Rhanterium and Zilla occur in this region. Other species such as Cornulaca monacantha, Haloxylon ammodendron, Hammada salicornica, Lasiurus scindicus, Heliotropium spp. and Stipagrostis spp. are amongst the most common in this area. 


\section{b. Arabian regional subzone ( $S S 2$ )}

The limits of the Arabian regional subzone (of the Saharo-Sindian regional zone) are restricted more or less to the sand deserts of Iraq bordering the deserts of Saudi Arabia. The vegetation of this zone fits in with the Psammophilous and Hamada (pro parte) vegetation described by White (1983), with many species of these vegetation types found in the deserts of Iraq. Saharo-Sindian endemics such as Astragalus tribuloides, Bassia muricata and B. eriophora (see maps in Akhani \& Khoshravesh, 2013), Cakile arabica, Centaurea spp., Cornulaca, Hammada salicornica, Paronychia arabica, Rhanterium epapposum, Rhazya stricta, Scrophularia desertii and Suaeda aegyptiaca also occur in this zone in Iraq.

\section{c. Nubian-Sindian local centre of endemism (SS3)}

Ecoregion: Red Sea Nubo-Sindian tropical desert and semi-desert; South Iran NuboSindian desert and semi-desert.

This is represented in Iraq by a few relictual floristic elements and is difficult to distinguish as a separate region. It is represented by species such as Ziziphus nummularia, Acacia pachyceras and Cleome amblyocarpa, which are Sudanian relicts that migrated from western Arabia through flow cut channels during pluvial times in the late Pliocene (c.2.5 MYBP) (Mandaville, 1984).

\section{ii. Irano-Turanian regional centre of endemism}

Ecoregion: Mesopotamian shrub desert; Middle East steppe; Zagros Mountains forest steppe.

The Irano-Turanian regional centre of endemism occupies the dry and moist steppes, foothills and mountains of Iraq (W Irano-Turanian Subregion; Zohary, 1973). This region is the most species rich in Iraq and also contains most of the endemic taxa. It is divided into (a) the Mesopotamian province and (b) the Irano-Anatolian province.

a. The Mesopotamian province extends from the northeastern Syrian Desert through the uplands and great outwash plain of northwestern Iraq, parts of the southern Anatolian plains and some parts of the Iranian plateau. In Iraq, it occupies areas of northern Iraq up to the foothills of the Kurdistan Mountains. Much of this area is heavily cultivated and the natural vegetation has disappeared; however, in non-cultivated areas, typical Irano-Turanian elements such as Artemisia inculta are present. Segetal associations are rich in species especially geophytes (Allium, Bellevalia, Asphodeline, Ixioliron) and in fallow fields a post-segetal community of Phlomis and Gundelia is present. Prosopis farcta is the common woody species in all habitats. In terms of natural vegetation, this region merges into the Saharo-Sindian zone in the south due to gradual climatic and topographical changes and can be considered as a transition zone between the two phytochoria. Saharo-Sindian elements include Stipa capensis, Psylliostachys spicata, Aizoon hispanicum and Arnebia cornuta. In non-cultivated areas, Poa bulbosa s.1. can be present with Stipa communities. Further north, the 
characteristic Artemisia herba-alba-Noaea mucronata association prevails, though in the Erbil-Mosul area an association of Poa bulbosa-Ranunculus asiaticus dominates. Other Irano-Turanian elements, such as Teucrium polium, Gundelia tournefortii, Phlomis spp., Salvia syriaca, Cousinia stenocephala and Centaurea behen, are found in different associations.

b. The Irano-Anatolian province comprises mainly the mountainous areas of Turkey and Armenia, the Iranian mountain plateau and the greater part of Transcaspia (Guest \& Al-Rawi, 1966; Zohary, 1973). In Iraq, it consists of the Kurdistan mountain forest and alpine regions and corresponds with the Middle East steppe and the Zagros Mountains forest steppe ecoregions. This region is rich in endemic species, with about a quarter of the total species found only there. It also contains most of the endemic species found in Iraq (Fig. 6). Irano-Turanian elements include Quercus spp. (Q. aegilops, Q. brantii, $Q$. infectoria, $Q$. libani) that form forests associated with other species such as Pistacia atlantica, P. khinjuk, Crataegus spp., Acer and Lonicera arborea. Low shrubs and ground vegetation include Chrozophora tinctoria, Echinops viscosus, Teucrium polium and Phlomis kurdica. Forested areas in Iraq are variously degraded through cutting and clearing but examples of almost closed forests still remain at a few inaccessible locations. In restricted localities, Pinus brutia var. eldarica is dominant (Farjon \& Filer, 2013, Map EM-15, p. 149), associated with Quercus aegilops, Q. infectoria and Juniperus oxycedrus. Above the timber line (1800-2000 m), the shrubs Lonicera acuminata, Cotoneaster racemiflora and Lonicera arborea form a narrow transition zone between the Forest and the Thorn-cushion Zones. IranoTuranian elements in the Thorn-cushion Zone include species of Astragalus, Acantholimon, Acanthophyllum and Onobrychis.

\section{iii. Mediterranean-Saharan regional transitional zone}

Ecoregion: Eastern mediterranean conifer-sclerophyllous broad leaf forest.

This territory occupies a narrow belt along the Mediterranean coast of Israel, Lebanon, Syria and Turkey. Even though Iraq has no truly Mediterranean territory, its flora includes a high percentage of Mediterranean plants. This is primarily because the western part of the Mesopotamian region of Iraq borders Turkey which is part of the Mediterranean floristic region. A large part of the Mediterranean flora in Iraq consists of segetal and ruderal plants belonging mainly to the families Asteraceae, Brassicaceae, Caryophyllaceae, Fabaceae and Poaceae. Trees and shrubs of the Kurdistan forest include Quercus boissieri, Q. libani, Pinus brutia var. eldarica, Crategeus aronia, Juniperus oxycedrus, Fraxinus rotundifolia and Platanus orientalis. Zohary (1973) considers that these may be either the easternmost Mediterranean flora or relics of the Tertiary Mediterranean vegetation that once existed on the borders of the Tethys Sea. The latter is true of Pinus brutia var. eldarica which is found only in the northern part of Iraq in the Irano-Turanian zone (Farjon \& Filer, 2013, Map EM-15, p. 149). 
Alpine and sub-alpine plants above the tree line, such as species of Astragalus, Onobrychis, Acantholimon, Acanthophyllum, Cousinia, Minuartia and Potentilla, can be considered bi-regional, occurring both in the Irano-Turanian and Mediterranean regions but with origins in the Irano-Turanian floristic region. However, species such as Sideritis libanotica, Lamium striatum, Nepeta orientalis, Cercis siliquastrum, Dianthus anatolicus and Myrtus communis can be considered true Mediterranean elements with origins in the East Mediterranean floristic region.

\subsubsection{Local centres of endemism}

Although data on endemic plants and their distributions are incomplete, three local centres of endemism can be distinguished.

\section{(i) The northern mountains of Iraq}

The northern mountains of Iraq in Kurdistan are an extension of the alpine system that runs eastward from the Balkans through southern Turkey, northern Iraq, Iran and Afghanistan, eventually reaching the Himalayas. In Iraq, the mountains in the Amadiyah, Rowanduz and Sulimaniyah districts have the highest number of endemic and near endemic species, in particular Jebel Avroman (Hauraman, Shakh-i Hauraman, $35^{\circ} 16^{\prime} \mathrm{N}$ $46^{\circ} 08^{\prime} \mathrm{E}$, District MSU), a mountain range (alt. $\pm 2500 \mathrm{~m}$ ) running along the Iranian frontier 15-25 km NE and N of Halabja and Pira Magrun $\left(35^{\circ} 46^{\prime} \mathrm{N} 45^{\circ} 14^{\prime} \mathrm{E}\right.$, District MSU), and a high mountain peak (alt. $\pm 2800 \mathrm{~m}$ ) about $30 \mathrm{~km} \mathrm{NW}$ of Sulaimaniyah.

Plants \pm 1350 spp.; endemism 31 spp., + 17 near endemics (Table 3; Fig. 6).

(ii) Jebel Sinjar $\left(36^{\circ} 25^{\prime} \mathrm{N} 41^{\circ} 50^{\prime} \mathrm{E}\right.$, District MJS), a small mountain range (alt. $\pm 1460 \mathrm{~m}$ ) running $\mathrm{W}-\mathrm{E}$ for $40-50 \mathrm{~km}$ from $\pm 100 \mathrm{~km}$ W of Mosul westwards to the Syrian frontier.

Plants \pm 406 spp.; endemism 7 spp.

(iii) The Tigris-Euphrates alluvial salt marshes (Central Alluvial Plains District and Southern Marsh District).

This is a complex of shallow freshwater lakes, swamps, marshes and seasonally inundated plains between the Tigris and Euphrates rivers. Permanent lakes, Haur al Hammar, the Central Marshes and Haur al Hawizeh as well as more seasonal 'ahrash' forest of Populus and Tamarix on islands and banks of the two rivers are included in this area (Evans, 1994). The aquatics Phragmites, Typha and Cyperus (papyrus) and halophytes Salicornia, Halocnemum and Suaeda are dominant in this region (Rechinger, 1964; Stattersfield et al., 1998). It is also amongst the most important wintering areas for migratory birds in Eurasia (Evans, 1994). A detailed distribution of the family Amaranthaceae (including Chenopodiaceae) shows that the family is dominant in the Lower Mesopotamian Region, especially in the Central Alluvial Plains District and in the Western Desert District in the Desert Plateau Region (Imperial-RBG Kew Conservation Science MSc, 2012, ined.; Fig. 12).

Plants \pm 800 spp.; endemism 6 spp. 


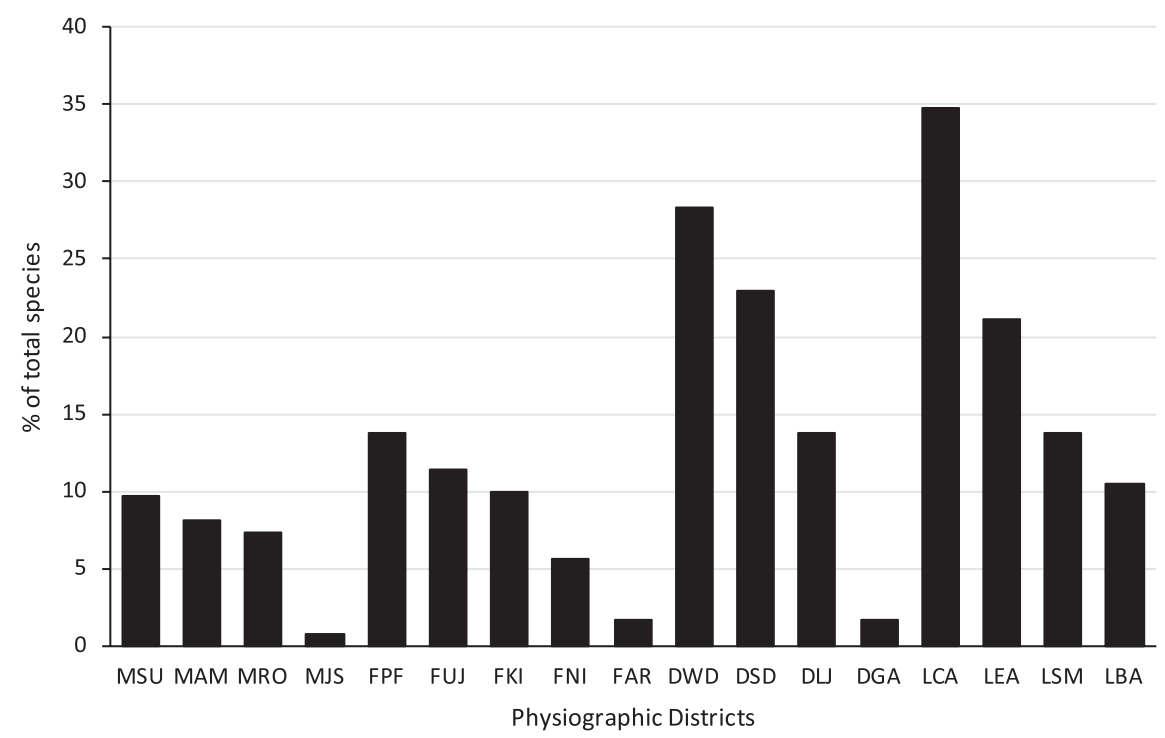

FIG. 12. Distribution of Amaranthaceae (including Chenopodiaceae) in the different physiographic districts of Iraq. Left to right: Mountain Region; Upper Plains and Foothills Region; Desert Plateau Region; Lower Mesopotamian Region.

\section{CONCLUDING REMARK}

Extensive survey work has been carried out during the last five years by Nature Iraq and the Ministry of the Environment to document the floral and faunal wealth of the country and to identify Key Biodiversity Areas and assess their conservation status (National Report on Biodiversity in Iraq, 2010). The report suggests that, of the ecoregions of Iraq, the Tigris-Euphrates alluvial salt marsh, the Arabian Desert and East Saharo-Arabian xeric shrublands and the Zagros Mountains forest steppe are Critical/Endangered, whilst the Mesopotamian shrub desert and the Middle East steppe regions are Vulnerable. Extensive logging of the oak-dominant deciduous forests in northern Iraq, poor agricultural practices, expansion of building and development sites, lack of proper legislation and a lack of designated nature reserves have been identified as key factors that have led to the degradation of biodiverse habitats over a period of time. As a signatory to the Convention on Biological Diversity (in 2009), Iraq is taking steps to update and improve documentation of their biodiversity and its conservation.

\section{ACKNOWLEDGEMENTS}

The first author is grateful to Jo Osborne and Renata Borosova for their input and help with Iraq plant distribution data and to the Imperial College \& Kew Conservation Science MSc Student Group 2012 for analysing some of the distributions. 
Tom McDaniel would like to thank Gwil Lewis, Maria Vorontosova and Gemma Bramley for help with Fabaceae, Poaceae and Lamiaceae, respectively. Saman Abdulrahman provided information on endemism and conservation status of Iraq mountain flora.

\section{REFERENCES}

A bDel-BARi, E. M. (2012). The Flora of Qatar. Vols 1 \& 2. Qatar University.

Акналі, H. (2006). Flora Iranica: facts and figures and a list of publications by

K. H. Rechinger on Iran and adjacent areas. Rostaniha 7 (Suppl. 2): 19-61.

Akнani, H. \& Khoshravesh, R. (2013). The relationship and different C-4 Kranz anatomy of Bassia eriantha and Bassia eriophora, two often confused Irano-Turanian and Saharo-Sindian species. Phytotaxa 93(1): 1-24.

Al-Dabias, M. A., Aвbas, M. A. \& Al-Khafaji, R. M. (2012). Dust storms loads analyses - Iraq. Arab. J. Geosci. 5: 121-131.

Al-Khulaidi, A. W. A. (2013). Flora of Yemen. Sustainable Natural Resource

Management Project (SNRMP) II. Obaidi Publishing.

Al-RAwi, A. (1987). Flora of Kuwait. Vol. 2: Monocotyledoneae. London: KPI Limited, \& University of Kuwait.

B At Anouny, K. H. (1981). The Ecology and Flora of Qatar. University of Qatar.

Boissier, E. (1867-1888). Flora Orientalis. Vols 1-5 \& Supplement. Geneva.

Boulos, L. (1999-2005). Flora of Egypt. Vols 1-4. Al-Hadara Publishing.

Boulos, L. (2009). Flora of Egypt Checklist. Al-Hadara Publishing.

Chaudhar y, M. (1999-2001). Flora of the Kingdom of Saudi Arabia. Vols 1-3. Saudi Arabia: Ministry of Agriculture.

Cornes, M. D. \& Cornes, C. D. (1989). The Wild Flowering Plants of Bahrain. Immel Publishing.

Daoud, H. S. \& Al-R awi, A. (1985). Flora of Kuwait. Vol. 1: Dicotyledoneae. London: KPI Limited, \& University of Kuwait.

Davis, P. (1965-1985). Flora of Turkey. Vols 1-10. Edinburgh University Press.

Duamali, M., Akhani, H., Khoshravesh, R., Andrieu-Ponel, V., Ponel, P. \& BREWER, S. (2011). Application of the Global Bioclimatic Classification to Iran: implications for understanding the modern vegetation and biogeography. Ecol. Medit. 37(1): 91-114.

Evans, M. I. (1994). Important Birds Areas in the Middle East. Cambridge, UK: Birdlife International.

Farjon, A. \& Filer, D. (2013). An Atlas of the World's Conifers. Leiden: Brill.

Frey, W., Probst, W. \& Kürschner, H. (eds) (1986). A synopsis of the vegetation in Iran. In: Contributions to the Vegetation of Southwest Asia, pp. 9-43. Wiesbaden, Germany: L. Reichert.

GhaZAnfar, S. A. (2003). Flora of the Sultanate of Oman. Vol. 1: Piperaceae-Primulaceae (Text + photo CD-ROM). Scripta Botanica Belgica Series 25. Meise: National Botanic Garden of Belgium. 262 pp.

Ghazanfar, S. A. (2007). Flora of the Sultanate of Oman. Vol. 2: Crassulaceae-Apiaceae (Text + photo CD-ROM). Scripta Botanica Belgica. Meise: National Botanic Garden of Belgium. 220 pp.

Ghazanfar, S. A. (2015). Flora of the Sultanate of Oman. Vol. 3: Loganiaceae-Asteraceae (Text + photo CD-ROM). Scripta Botanica Belgica. Meise: National Botanic Garden of Belgium. 371 pp. (in press). 
Ghazanfar, S. A. \& Edmondson, J. R. (2013). Flora of Iraq. Vol. 5(2). Ministry of Agriculture \& Kew Publishing.

Ghazanfar, S. A. \& Fisher, M. (eds) (1998). Vegetation of the Arabian Peninsula. Dordrecht: Kluwer Academic Press. 362 pp.

Glennie, K. W. (1995). The Geology of the Oman Mountains: An Outline of their Origin. Beaconsfield: Scientific Press.

Glennie, K. W. (2005). The desert of southeast Arabia: a product of Quaternary climatic change. In: Alsharan, A. S., Glennie, K. W., Whittle, G. L. \& Kendall, C. G. S. C. (eds) Quaternary Deserts and Climate Change. Rotterdam: Balkema.

Guest, E. \& Al-RAwi, A. (1966). Flora of Iraq. Vol. 1. Ministry of Agriculture \& Kew Publishing.

Güner, A., Aslan, S., Ekim, T., Vural, M. \& BabaC,, M. T. (2012). Türkiye Bitkileri Listesi. Nezahat Gökyiğit Botanik Bahçesi ve Flora Arastirmalari Derneği Yayini. Istanbul.

Imperial-RBG Kew Conservation Science MSc. (2012). Distribution assessment of the Amaranthaceae in Iraq. Kew-based project. Unpublished.

Jong bloed, M. (2003). The Comprehensive Guide to the Wild Flowers of the United Arab Emirates. Environmental Research and Wildlife Development Agency.

Karim, F. M. \& Fawzi, N. M. (2007). Flora of the United Arab Emirates. Vols 1 \& 2. UAE University Publications.

LÉONAR D, J. (1981-1989). Contribution a l'étude de la flore et de la végétation des deserts d'Iran. Fasc. 1-9. Meise: Jardin botanique national de Belgique.

LÉona R D, J. (1989). Contribution a l'étude de la flore et de la végétation des deserts d'Iran. Fasc. 9: Considérations phytogeographiques sur les phytochories irano-turanianne, saharo-sindienne et de la Somalie-pays Masai. Meise: Jardin botanique national de Belgique.

Manda ville, J. P. (1984). Studies in the Flora of Arabia: XI. Some historical and geographical aspects of a principal floristic frontier. Notes Roy. Bot. Gard. Edinburgh 42: $1-15$.

Mandaville, J. P. (1990). Flora of Eastern Saudi Arabia. London: Kegan Paul International.

Mildrexler, D. J., Zhao, M. \& Running, S. W. (2005). Where are the hottest spots on earth? $\operatorname{EOS~87(43):~} 467$.

Mouter de, P. (1970). Nouvelle flore du Liban et de la Syrie. Beirut, Lebanon.

National Report on Biodiversity in Iraq (2010). Ministry of Environment, Iraq. http://www.cbd.int/doc/world/iq/iq-nr-04-en.pdf

Norton, J., Majid, S. A., Allan, D., Al Safran, M., Boer, B. \& Richer, R. (2009). An Illustrated Checklist of the Flora of Qatar. UNESCO Publication.

Olson, D. M., Dinerstein, E., Wikramanayake, E. D., Burgess, N. D., Powell, G. V. N., Underwood, E. C. ET AL. (2001). Terrestrial ecoregions of the world: a new map of life on Earth. Bioscience 51(11): 933-938.

Phillips, D. C. (1988). Wild Flowers of Bahrain: A Field Guide to Herbs, Shrubs and Trees. Manama, Bahrain.

Post, G. E. (1932-1933). Flora of Syria, Palestine and Sinai. Vols 1 \& 2. Beirut: American Press.

Rechinger, K. H. (ed.) (1963-2012). Flora Iranica (Flora des Iranischen Hochlands und der Umrahmenden Gebirge: Persien, Afghanistan, Teile von West Pakistan, Nord Iraq, Azerbaijan, Turkmenistan), pp. 1-179. Graz \& Wien: Akademsiche Druck- u. Verlagsanstalt und Naturhistorisches Museum Wien. 
Stattersfield, A. J., Crosby, M. J., Long, A. J. \& Wege, D. C. (1998). Endemic Bird Areas of the World: Priorities for Biodiversity Conservation. Cambridge, UK: Birdlife International.

Townsend, C. \& Guest, E. (1966-1985). Flora of Iraq. Vols 2, 3, 4(1), 4(2), 8 \& 9. Baghdad: Ministry of Agriculture.

Western, A. R. (1989). The Flora of the United Emirates: An Introduction. United Arab Emirates University.

White, F. (1983). The Vegetation of Africa: A Descriptive Memoir to Accompany the UNESCOIAETFATIUNSO Vegetation Map of Africa. Paris: UNESCO.

White, F. \& LÉonard, J. (1991). Phytogeographical links between Africa and Southwest Asia. Fl. Veg. Mundi 9: 229-246.

Wood, J. R. I. (1997). A Handbook of the Yemen Flora. Kew Publishing.

Zohar y, M. (1966-1986). Flora Palaestina. Vols 1-4. Jerusalem: Israel Academy of Sciences and Humanities.

Zohar y, M. (1973). Geobotanical Foundations of the Middle East. 2 vols. Gustav Fischer Verlag.

Zohary, D., Hopf, M. \& Weiss, E. (2012). Domestication of Plants in the Old World: The Origin and Spread of Domesticated Plants in South-West Asia, Europe and the Mediterranean Basin. Oxford: Clarendon Press.

Received 6 May 2014; accepted for publication 10 June 2015;

first published online 26 October 2015 